\title{
REDESAIN RANCANGAN UNDANG UNDANG OMNIBUS LAW CIPTA LAPANGAN KERJA
}

\author{
Basuki Kurniawan \\ Dosen Fakultas Syari'ah IAIN Jember \\ e-Mail: basukikurniawanlaw@gmail.com
}

\begin{abstract}
Iklim investasi sulit berkembang bilamana terlalu banyaknya aturan yang tumpang tindih dari pusat hingga daerah, serta dengan prosedur perizinan yang lama menjadi suatu sumber masalah yang tidak kunjung selesai. Melihat hal tersebut Presiden Jokowi membuat trobosan dengan menggunakan Omnibus Law Cipta Lapangan Kerja atau sering kali disebut dengan RUU Omnibus Law Cilaka. Hal ini merupakan sesuatu yang baru di Indonesia, namun itu merupakan suatu terobosan dalam menyelesaikan kesemerawutan hukum di Indonesia. Namun keinginan dari Pemerintah mendapatkan respon gelombang demo yang cukup besar dari golongan buruh dan masyarakat. Demo itu didasarkan isi dari pasal-pasal dalam RUU Omnibus Law Cipta Lapangan Kerja yang dianggap merugikan masyakat Indonesia dan golongan buruh. Berdasarkan pendapat yang penulis sampaikan, kami menyimpulkn beberapa hal. Pertama, RUU Omnibus Law Cipta Lapangan Kerja memiliki beberapa koreksi yang lebih dalam khususnya dalam aspek paradigma serta substansi pengaturan mengenai PHK, Izin, serta Otonomi Daerah (Desentralisasi). Kedua, niatan adanya RUU Omnibus Law Cilaka yakni untuk mengurangi adanya hyper regulation (banyaknya peraturan perundang-undangan), namun dalam RUU malah menciptakan aturan turunan yang membuat semakin banyaknya aturan baru yang dimunculkan. Maka seyogyanya RUU Omnibus Law Cipta Lapangan Kerja ini perlu di atur ulang dengan tetap mengikut sertakan masyarakat luas dalam memberikan masukan dan pandangan demi sempurnanya RUU Cipta Lapangan Kerja ini.
\end{abstract}

Kata Kunci: Omnibus Law, Cipta Lapangan Kerja.

\section{PENDAHULUAN}

Banyaknya aturan yang tumpang tindih, dan juga iklim investasi yang sangat dibutuhkan agar tumbuh secara signifikan dalam persaingan dengan dunia global, tentu untuk mengatur tersebut diperlukan suatu aturan yang dapat menampung banyaknya aturan yang ada di Indonesia. Semenjak Indonesia merdeka pada tahun 1945, Pemerintah (eksekutif dan legislatif) memproduksi peraturan perundang-undangan untuk mengatur masyarakat baik dalam bentuk regeling (peraturan) dan beschikking (keputusan). 
Banyaknya aturan yang tumpang tindih itu kemudian banyak yang diajukan judicial review atau pengujian peraturan perundang-undangan ke Mahkamah Konstitusi Republik Indonesia. Sejak berdirinya Mahkamah Konstitusi pada tahun 2003, banyak UU diajukan ke MK karena dianggap bertentangan dengan UUD Negara Republik Indonesia tahun 1945. Dan memang betul kiranya bahwasanya peraturan tersebut juga oleh Mahkamah Konstitusi di batalkan dan dianggap bertentangan dengan Konstitusi Negara Republik Indonesia.

Sejak berdirinya Negara Republik Indonesia, para the founding father and mothers sepakat untuk membentuk negara yang baru merdeka itu dengan sebutan sebagai negara Hukum $^{12}$, yang pada penerapannya di sesuaikan dengan aturan-aturan yang mengatur masyarakat (rule of law). ${ }^{13}$ Terlebih lagi dengan fakta sejarah bangsa Indonesia yang pernah di jajah oleh Belanda dan berkembang beberapa hukum yakni hukum Belanda (Wetboek van Strafrecht), Hukum Islam dan Hukum Adat. Mengingat penerapan hukum yang digunakan bangsa Indonesia cukup beragam, maka dalam unifikasi (penyatuan) hukum sangat diperlukan untuk mengatur seluruh warga negara Indonesia.

Memasuki periode kedua masa kepemimpinan Presiden Joko Widodo, untuk meningkatkan investasi dan ekonomi, Pemerintahan Presiden Jokowi (nama panggilan) membuat suatu terobosan dalam meningkat investasi di Indonesia agar bisa bersaing dengan bangsa-bangsa lain. Yang kita ketahui bahwa Indonesia banyak berkembang usaha start up (perusahaan rintisan) yang berkembang dari unicorn menjadi decacorn karena valuasi usaha seudah lebih dari 10 triliyun. Maka dalam pengembangan suatu iklim investasi perlu dilindungi oleh aturan-aturan terkait yang mendukung iklim investasi.

Iklim investasi sulit berkembang bilamana terlalu banyaknya aturan yang tumpang tindih dari pusat hingga daerah, serta dengan prosedur perizinan yang lama menjadi suatu

\footnotetext{
12 Lihat Pasal 1 Ayat (3) UUD NRI Tahun 1945 yang menyatakan bahwa " Indonesia adalah negara Hukum".

${ }^{13}$ Rule of law merupakan konsep pengaturan negara yang membedakan antara negara kekuasaan (machtstaat) dan negara hukum (rule of law) atau juga biasa disebut dengan rechtsstaat. Lihat Basuki Kurniawan, Persamaan Hak Pilih TNI Polri dalam Pemilihan Umum di Indonesia, Tesis, (Jember: Universitas Jember), 2014, hlm. 56
} 
sumber masalah yang tidak kunjung selesai. Melihat hal tersebut Presiden Jokowi membuat trobosan dengan menggunakan Omnibus Law Cipta Lapangan Kerja atau sering kali disebut dengan RUU Omnibus Law Cilaka. Hal ini merupakan sesuatu yang baru di Indonesia, namun itu merupakan suatu terobosan dalam menyelesaikan kesemerawutan hukum di Indonesia. Namun keinginan dari Pemerintah mendapatkan respon gelombang demo yang cukup besar dari golongan buruh dan masyarakat. Demo itu didasarkan isi dari pasal-pasal dalam RUU Omnibus Law Cipta Lapangan Kerja yang dianggap merugikan masyakat Indonesia dan golongan buruh.

Awal tahun 2020 tepatnya tanggal 13 Februari 2020 Pemerintah Indonesia menyerahkan secara legal Rancangan Undang-Undang Cipta Lapangan Kerja, yang mana itu merupakan suatu aturan perundang-undangan inisiatif dari eksekutif kepada Legislatif Dewan Perwakilan Rakyat Indonesia. RUU Omnibus Law Cilaka ini dalam teknis penyusunannya itu menerapkan konsep omnibus law yang ramai digunakan di negara Common Law, sedangkan Indonesia menerapkan sistem hukum Civil law. Dalam RUU Cilaka tersebut mencakup sebelas bidang kebijakan seperti berikut ini:

1. Penyederhanaan perizinan

2. Persyaratan investasi

3. Ketenagakerjaan

4. Kemudaha, pemberdayaan, dan perlindungan UMKM dan Perkoperasian

5. Kemudahan Berusaha

6. Dukungan Riset dan Inovasi

7. Administrasi Pemerintahan

8. Penerapan Sanksi

9. Pengadaan tanah, alih fungsi lahan pertanian, Pertanahan, dan Isu terkait lainnya

10. Investasi dan Proyek Strategi Nasional

11. Kawasan Ekonomi

Perlu kita ketahui bersama bahwasannya dalam RUU Omnibus Law Cilaka ini berjumlah 174 Pasal, tetapi secara substansi memuat beberapa perubahan dan pembatalan norma atas 79 undang-undang yang menjadi inti aturan dalam beberapa sektor. Kemudian, 
RUU Cilaka ini juga mengatur ulang kurang lebih 500 peraturan pelaksana untuk melengkapi pengaturan 11 bidang yang ditulis pada paragraf sebelumnya.

Mulai digagaskan sebagai inisiatif dari eksekutif hingga penyerahannya ke anggota dewan legislatif, RUU Omnibus Law Cilaka ini sudah membuat panas dingin situasi masyarakat. Kelompok masyarakat yang sudah sedikit banyak memahami hukum, mulai membaca dan menganalisis isi aturan dalam Rancangan UU tersebut, dan banyak yang tidak setuju dan ada juga yang mendukung inisiatif dari Pemerintah tersebut.

Melihat fenomena tersebut, penulis menganggap penting untuk mengangkat isu hukum mengenai omnibus law itu dalam diskusi periodik. RUU Omnibus Law Cilaka menjadi kajian hukum yang menarik untuk ditemukan solusinya agar amanah konstitusi dalam mensejahterakan warga negara Indonesia dapat tercapai dengan sesungguhnya.

\section{Masalah atau Topik Bahasan}

Sesuai dengan uraian dari latar belakang penulisan diatas, maka penulis menyusun rumusan masalah dalam makalah ini yakni sebagai berikut:

1 Apakah RUU Omnibus Law Cipta Lapangan Kerja itu sesuai dengan rasa keadilan pekerja/ buruh?

2. Bagaimana mendesaian ulang RUU Cipta Lapangan Kerja pada otonomi daerah/ desentralisasi ?

\section{PEMBAHASAN}

Dalam menganalisis RUU Omnibus Law Cipta Lapangan Kerja atau sering disebut dengan RUU Cilaka ini ada beberapa hal menarik yang perlu didiskusikan bersama.

\section{A. Adanya Sentralisasi Perizinan yang berdampak pada Desentralisasi/ Otonomi Daerah.}

RUU Cilaka ini akan membuat tidak diberlakukan lagi pasal terkait dengan kewenangan daerah di UU Induknya. Kewenangan yang tercantum dalam pasal tersebut 
akan dibalikkan kepada Pemerintah Pusat. Pengaturan tersebut dalam Politik Hukum bisa dengan banyak cara, seperti halnya bisa dibentuk dengan Peraturan Pemerintah, Peraturan Menteri, Peraturan Presiden, dan peraturan lain yang menyangkut tentang kewenangan Pemerintah Pusat. Padahal secara praktis sumber daya Pemerintah Pusat dalam mengatur secara kompleks pemerintah daerah masih minim, terlebih lagi setelah adanya penerapan otonomi daerah.

Maknanya dengan adanya pengambilan wewenang dari daerah ke pusat akan mengakibatkan pelemahan dari sisi pemerintah daerah. Dampak yang jelas terasa adalah adanya pelemahan yang dirasa oleh pemerintah daerah.

Sebut saja tentang perubahan terhadap proses AMDAL yang sudah diketahui bersama bahwa itu merupakan pembagian kewenangan pemerintah pusat, pemerintah provinsi, dan pemerintah kabupaten/ kota. Dalam RUU Omnibus Law Cilaka tersebut kewenangan mengenai proses AMDAL akan menjadi kewenangan penuh pemerintah pusat, hal itu tertuang dalam Pasal 23 angka 4 RUU Cipta Lapangan Kerja a quo, yang merupakan bentuk perubahan dari Pasal 63 UU tentang Perlindungan dan Pengelolaan Lingkungan Hidup. ${ }^{14}$

\section{Proses Izin}

RUU Omnibus Law Cipta Lapangan Kerja membuat sederhana perihal perizinan yaitu dengan proses pengurusan yang relatif singkat, prosedur yang terlalu rumit serta biaya yang bisa dibilang murah. ${ }^{15}$ Penyederhanaan ini tentu sangat mendukung iklim investasi yang mengharus segala hal harus bergerak cepat mengikuti perubahan zaman. Penyederhanaan yang penulis maksud seperti berikut

Pertama, Pendirian bangunan, RUU Cilaka akan menghapus segala persyaratan administratif yang tercakup dalam persyaratan status hak atas tanah, status hak milik bangunan gedung serta izin mendirikan banguan (IMB). ${ }^{16}$ Persyaratan tersebut diubah

\footnotetext{
14 Lihat pada Pasal 23 angka 4 RUU Cipta Lapangan Kerja

15 Terpetik dari BPHN, Naskah Akademik RUU Cipta Lapangan Kerja, 2020, hlm. 121.

16 UU No. 28 Tahun 2002 tentang Bangunan Gedung yang menyatakan bahwa setiap bangunan gedung harus memenuhi persyaratan administratif dan persyaratan teknis sesuai dengan fungsi bangunan Gedung. Lihat juga UU No. 28 Tahun 2002 tentang Bangunan Gedung Pasal 7 Ayat (1).
} 
dengan keharusan bagi setiap bangunan gedung untuk memenuhi standar teknis bangunan agar menyerupai fungsi dan klasifikasi bangunan. ${ }^{17}$

Kedua, Perizinan untuk Kegiatan Investasi dan berusaha, dalam RUU Omnibus Law Cilaka juga memanage tentang Perizinan Berbasis Resiko. Model perizinan seperti ini mengharuskan klasifikasi usaha yang syarat perizinannya akan mengadaptasi dengan resiko dari usaha tersebut. Penilaian resiko ditinjau dari aspek kesehatan, keselamatan, lingkungan, dan atau pemanfaatan sumber daya, dilakukan dengan mengkalkulasikan jenis aktivitas usaha, dan/ atau keterbatasan sumber daya. ${ }^{18}$ Sesuai dengan amanah pasal 8 Ayat (7) RUU Cilaka, kegiatan usaha beresiko tinggi memerlukan Izin mendirikan bangunan. Hal tersebut (izin) merupakan persetujuan Pemerintah Pusat agar melakukan aktivitas usaha yang wajib dipenuhi oleh pelaku usaha sebelum usaha tersebut dijalankan atau dikembangkan.

Dampak dari aturan pemerintah mengenai Perizinan Berusaha berbasis resiko adalah Pemerintah harus menyusu klasifikasi yang clear tentang jenis usaha dan jenis izin yang akan diterapkan. Aturan mengenai perizinan berusaha ini harus diatur dalam peraturan pelaksanaannya di dalam Peraturan Pemerintah.

\section{B. Bidang Ketenagakerjaan}

RUU Omnibus Law Cipta Lapangan Kerja ini lebih memiliki kecenderungan dalam peningkatan perekonomian, dan kurang memperdulikan terhadap peningkatan kualitas sumber daya manusia. Pasal 88 RUU Omnibus Law Cilaka menyatakan bahwa pengaturan yang terupdate yang ada dalam RUU ini bertujuan untuk menguatkan perlindungan kepada tenaga kerja dan meningkatkan kepada tenaga kerja dalam mendukung dunia investasi di Indonesia. Hal tersebut dapat dipetik bahwa RUU Cilaka ini lebih mengedepankan investasi seta pembangunan ekonomi merupakan hal paling penting dalam pembangunan suatu bangsa. Kebanyakan peraturan yang sudah di ubah dan diatur dalam RUU ini acapkali menyebutkan efisiensi dan peningkatan produktifitas tenaga kerja.

17 Terpetik dari Pasal 7 Ayat (1) UU Nomor 28 Tahun 2002 tentang Bangunan Gedung.

18 Lihat Pasal 8 ayat (5) RUU Cipta Lapangan Kerja. 
Padahal dalam membicara produktifitas tenaga kerja itu yang terpenting adalah pelatihan dan training. Karena dalam Manajemen Sumber Daya Manusia, apabila berbicara peningkatan produktifitas pekerja Indonesia itu harus disertai pelatihan dan training yang intens. Pelatihan yang intens akan membentuk pekerja semakin kreatif dan produktif dalam bidang pekerjaannya.

Berbicara mengenai cipta lapangan kerja maka kita akan berbicara mengenai kualitas pekerja. Kualitas pekerja bisa dinilai dari pendidikan dan pelatihan. Maknanya bilamana RUU Cipta Lapangan Kerja, maka yang harus di pentingkan itu adalah pendidikan dan pelatihan/ training. Maksudnya bilamana pekerja Indonesia memiliki pendidikan yang bagus, pelatihan yang tingkat excellent maka pekerja akan lebih produktif dan kita tidak akan kalah oleh pekerja asing. Kekhawatiran dari penulis bilamana RUU Omnibus Law Cipta Lapangan Kerja ini langsung di sahkan, tanpa adanya masukan/ partisipasi dari masyarakat, maka yang dirugikan adalah pekerja Indonesia.

Tenaga kerja asing mulai menyerbu masuk di lingkungan kerja wilayah Indonesia. Perusahaan mengambil tenaga kerja asing dengan alasan karena pekerja asing memiliki kompetensi yang tidak dimiliki oleh pekerja Indonesia. Maknanya RUU Omnibus Law Cipta Lapangan Kerja juga harus berfokus untuk meningkatkan produktifitas pekerja Indonesia. Dengan fokus pada peningkatan produktifitas pekerja Indonesia maka ada atau tidak ada omnibus law, maka pekerja Indonesia akan sejahtera. Karena dasar filosofis adanya peraturan adalah untuk mensejahterakan masyarakat.

\section{a. Perubahan mengenai Upah Minimum}

Setiap 1 Mei selalu dilaksanakan hari buruh, yang mana pada tanggal tersebut dimanfaatkan oleh para buruh untuk melampiaskan unek-uneknya, dan yang sering menjadi tuntutan adalah upah minimum. Dalam UU Ketenagakerjaan mengenai upah minimum dapat dilihat dari wilayah provinsi dengan upah minimum provinsi (UMP) dan Upah minimum kabupaten/kota (UMK). Maka dengan adanya RUU Cilaka ini hal tersebut (UMK dan UMP) tidak akan berlaku lagi. RUU Omnibus Cipta Lapangan Kerja menyatakan bahwa pasal 88C yakni: (1) Gubernur menetapkan upah minimum sebagai jaring 
pengaman. (2) Upah minimum sebagaimana dimaksud pada ayat (1) merupakan upah minimum provinsi.

Dari pasal 88C ayat (1) dan (2) dapat kita tafsiri bahwa bilamana RUU Cipta Lapangan Kerja ini goal di DPR, maka tidak akan ada lagi yang namanya Upah Minimum Kabupaten/ Kota, karena yang berlaku adalah Upah Minimum Provinsi. Padahal yang kita ketahui saat ini Upah Minimum Kabupaten/ Kota lebih tinggi dari pada upah minimum provinsi. Pertanyaannya seberapa urgenkah penghapusan UMK itu dalam RUU Cilaka? ${ }^{19}$

\section{b. Perubahan makna Pemutusan Hubungan Kerja}

Pasal 151 ayat (1) UU Ketenagakerjaan mengatur tentang Pemutusan Hubungan Kerja namun dalam RUU Cilaka ada sedikit perubahan tentang penafsiran dari PHK. Perubahan ini yakni menghilangkan konsepsi awal mengenai PHK dalam UU Ketenagakerjaan yang harus dilihat sebagai sesuatu yang harus dijauhi. Rumusan Pasal 151 Ayat (1) pada RUU Omnibus Law Cilaka. PHK merupakan hal yang cukup privasi antara pengusaha dan pekerja/ buruh. Di tambah lagi saat serikat buruh mempunyai peran krusial bilamana terjadi pemutusan hubungan kerja dalam menjembatani pengusaha dan buruh, mediasi yang dilakukan oleh serikat pekerja ini menjadi cara penyelesaian sengketa akan tercipta win-win solution. Namun dalam RUU Cilaka pasal 151 ayat (2) merubah konsep PHK, yakni penyelesaian Pemutusan Hubungan kerja melalui penetapan lembaga penyelesaian perselisihan hubungan Industrial.

Dalam RUU Cipta Lapangan Kerja yang hangat saat ini juga memberikan kekuasaan yang lebih kepada pengusaha dalam pemutusan hubungan kerja tanpa perlu adanya kesepakatan dan/ atau prosedur penyelesaian yang mengharuskan penyelesaian secara triparti dan bipartit sesuai dengan sengketa hubungan industrial.

Pasal 156 RUU Cilaka juga menghilangkan kewajiban perusahaan untuk memberikan uang penggantian hak. ${ }^{20}$ Menilai pentingnya uang penggantian pada saat pemutusan

${ }^{19}$ Lihat Peraturan Pemerintah Nomor 78 Tahun 2015 tentang Pengupahan.

${ }^{20}$ Undang-Undang Ketenagakerjaan mewajibkan adanya uang penggantian hak, tapi pada RUU Cipta Lapangan Kerja Pasal 156 Ayat (4) mengatur pengusaha dapat memberikan uang 
hubungan kerja maka alangkah baiknya RUU Cilaka mengenai uang penggantian saat PHK perlu dikaji ulang, karena hal tersbeut untuk melindungi hak dari pekerja yang sudah mengabdi kepada perusahaan.

\section{Kaitan RUU Cipta Lapangan Kerja dengan Administrasi Pemerintahah}

\section{a. Kewenangan Presiden}

Dalam RUU Cilaka pasal 164 pada dasarnya memang benar bilamana kewenangan yang dicantumkan dalam peraturan perundang-undangan itu merupakan kewenangan Presiden. ${ }^{21}$ Dalam doktrin hukum tata negara yang menganut asas sistem Presidensial, maka pengaturan tersebut menarik untuk difikirkan. Masalahnya setelah adanya reformasi ada konsep pembagian kekuasaan antara pemerintah pusat dan daerah. Yang mana peraturan-peraturan daerah, seperti perda, perbup itu diatur oleh daerah masing-masing. Maknanya presiden tidak bisa mengatur secara menyeluruh peraturan di daerah. Cuma dalam asas hierarki peraturan perundang-undangan, mengharuskan peraturan dibawah tidak boleh bertentangan dengan peraturan diatasnya. ${ }^{22}$

Problem yang muncul bilamana penerapan RUU Omnibus Law Cipta Lapangan Kerja ini adalah penghapusan Perda-perda di daerah, atau perda tersebut dicabut secara otomatis oleh Pemerintah Pusat. Padahal dalam paham pengujian peraturan perundangundangan harus melakukan judicial review, executive review ataupun legislatif review.

\section{b. Pengaturan mengenai Diskresi}

penggantian atua tidak memberikan uang penggantian, karena penafsiran "dapat" adalah pilihan yang diambil pengusaha.

${ }^{21}$ Lihat Undang-Undang Nomor 12 Tahun 2011 tentang Pembentukan Peraturan PerundangUndangan.

22 Dalam hierarkhi peraturan perundang-undangan yang diajarkan dalam Hans Nawiasky menerangakn ada UU yang tinggi dan UU yang bawah, di Indonesia penerapan peraturan perundang-undangan itu diatur berturut-turut sebagai berikut: (1) UUD NRI Tahun 1945, (2) Tap MPR, (3) Perppu/ UU, (4) Peraturan Pemerintah, (5) Peraturan Presiden, (6) Peraturan Daerah Provinsi, (7) Peraturan Daerah Kabupaten/Kota. Lihat UU No. 12 Tahun 2011 tentang Pembentukan Peraturan Perundang-Undangan. 
Diskresi atau discretion dan yang lebih dikenal dengan freis ermessen merupakan bentuk kebijakan pemerintah yang diakibatkan adanya force majeur sesuatu yang mendesak di perlukan kebijakan politik hukum segera mungkin. Pasal 165 RUU Cilaka mengubah beberapa ketentuan pada UU Administrasi Pemerintahan. Pada satu sisi, pasal ini mempermudah dalam menggunakan diskresi. Diskresi itu dimaknai sebagai salah satu cara yang memberikan ruang gerak bagi pejabat tata usaha negara atau badan-badan administrasi negara untuk melakukan suatu tindakan pemerintah, tanpa harus harus terikat sepenuhnya pada undang-undang. Namun bila kita telisik lebih dalam lagi pada UU Administrasi Pemerintahan terdapat ketentuan syarat penting diskresi yakni ketika tidak melanggar peraturan perundang-undangan .

Pada satu sisi, RUU Cilaka membuat diskresi cukup lebar dengan mekanisme kontrol dan pengawasan yang tidak cukup efektif. Masalah ini cukup bahaya bilamana disalahgunakan seperti adanya Kolusi, korupsi dan nepotisme. Dan akan merugikan keuangan negara bilamana tanpa adanya pengawasan yang kuat. Maka RUU cilaka ini masih perlu diperbaiki dalam sistem pengawasan pelaksanaan dari diskresi itu sendiri. Jangan sampai RUU Omnibus Law Cilaka yang baik, malah disalahgunakan bilamana tanpa adanya pengawasan yang baik dalam penggunaan kuasa anggaran.

\section{c. Makna dari Otonomi Daerah}

Pada Pasal 166-167 RUU Cipta Lapangan Kerja ini merupakan pasal yang bisa disamakan dengan UU sapu jagat, yang mengatur banyaknya UU diatur dalam satu UU dan itu tidak mudah dalam kontrol dan pelaksaannya. Terlebih lagi bagi pemerintah daerah, karena rezim sentralisasi yang pernah kita terapakan sudah berubah dengan konsep otonomi daerah (dekonsentrasi). Pembagian kekuasaan pusat dan daerah dalam pelaksaan RUU Cilaka ini menjadi point yang perlu untuk di tata lebih jauh.

Bilamana sistem sentralisasi atau terpusat di hidupkan kembali, maka kita akan melakukan kemunduran dalam demokrasi. Praktik ketatanegaraan saat ini sistem otonomi daerah mulai semakin dewasa, hal ini terbukti dalam pemilu dan peningkatan kesejahteraan di daerah semakin meningkat dari waktu ke waktu. Maka memang otonomi 
daerah ada kelemahan, tapi hanya perlu perbaikan setahap demi setahap, tidak untuk mundur kembali ke masa orde baru.

\section{KESIMPUAN DAN SARAN}

\section{A. Kesimpulan}

Berdasarkan pendapat yang penulis sampaikan diatas, kami menyimpulkn beberapa hal. Pertama, RUU Omnibus Law Cipta Lapangan Kerja memiliki beberapa koreksi yang lebih dalam khususnya dalam aspek paradigma serta substansi pengaturan mengenai PHK, Izin, serta Otonomi Daerah (Desentralisasi)

Kedua, niatan adanya RUU Omnibus Law Cilaka yakni untuk mengurangi adanya hyper regulation (banyaknya peraturan perundang-undangan), namun dalam RUU malah menciptakan aturan turunan yang membuat semakin banyaknya aturan baru yang dimunculkan.

\section{B. Saran}

Maka seyogyanya RUU Omnibus Law Cipta Lapangan Kerja ini perlu di atur ulang dengan tetap mengikut sertakan masyarakat luas dalam memberikan masukan dan pandangan demi sempurnanya RUU Cipta Lapangan Kerja ini.

\section{DAFTAR PUSTAKA}

Basuki Kurniawan, Persamaan Hak Pilih TNI Polri dalam Pemilihan Umum di Indonesia, Tesis, (Jember: Universitas Jember

BPHN, Naskah Akademik RUU Cipta Lapangan Kerja, 2020

Peraturan Pemerintah Nomor 78 Tahun 2015 tentang Pengupahan.

RUU Cipta Lapangan Kerja

Undang-Undang Ketenagakerjaan

Undang-Undang Nomor 12 Tahun 2011 tentang Pembentukan Peraturan PerundangUndangan. 
UU No. 28 Tahun 2002 tentang Bangunan

UUD NRI Tahun 1945

32 Universitas Borneo Tarakan 